\title{
SMILE Regimen
}

National Cancer Institute

\section{Source}

National Cancer Institute. SMILE Regimen. NCI Thesaurus. Code C140113.

A regimen consisting of dexamethasone, methotrexate, ifosfamide, L-asparaginase and etoposide that can be used in the treatment of natural killer (NK)/T -cell lymphoma. 